Bones for the Archaeologist

By Dr. I. W. Cornwall. Pp. 256. (London: Phoenix House, Ltd., 1956.) 50s. net.

A LTHOUGH the title of this book might at first glance suggest a light-hearted detective story, a suggestion which is perhaps enhanced by the gav picture on the cover of a skeletonized man on a skeletonized horse hunting a skeletonized stag with a skeletonized dog, it is a serious and systematic textbook designed to teach aspiring archæologists how to recognize and distinguish animal bones found in association with archæological relics. Detailed descriptions are given of the skull, dentition and limb bones of a varie $y$ of mammals likely to be found in palæolithic or later deposits, providing a useful key for their determination. Students will find that this text-book must be used essentially as a guide in the course of studying the actual skeletal elements described, for experience shows that, however careful and detailed the descriptive accounts may be, a learning of osteology is not to be acquired from books alone. The author has certainly done his work well so far as the systematic descriptions go, and he has incorporated useful sections dealing with the practical treatment of fossil bones in the field or in the laboratory. Except for those depicting the dentition of smaller creatures, which are rather too obscure, the illustrations are clear and precise, and in all cases the scale of drawing is indicated. A small point of criticism, perhaps of not great importance in a work of this kind, is that the author perpetuates a popular fallacy by his statement that it was Charles Darwin who first propounded the theory that all living species had developed from more primitive and simpler forms.

W. E. Le Gros Clatrk

The Bird Watcher's Reference Book

By Michael Lister. Pp. $256+16$ plates. (London : Phoenix House, Ltd., 1956.) 45s. net.

TSUALLY the authors of books written for birdwatchers occupy themselves with 'what' and 'how', devoting much space to descriptions of species, bird biology and field-work techniques. Mr. M. Lister does not follow this practice, devoting the general part of his book to problems which, although of great importance to every ornithologist, are seldom included in the bird books. Thus in this part of this ornithological book nothing is said about the bird itself, its life, behaviour, etc. Instead of this, the first four chapters deal with "Habitats, Vegetation, and Birds", "Types of British Vegetation", "Weather" and "On Writing a Paper". All matters discussed here are of great interest for every ornithologist and it is very good indeed that, at last, they have been presented to him in detail. Chapter 5-"Directory" - contains information referring to periodicals, institutions, bird observatories and ringing schemes, in almost every country of the world. The amount of information gathered by the author shows how much effort and labour had to be made to reach such an excellent result. Objection could be raised only with reference to North American ornithological life, which seems to be treated with a little less care; but on the whole this directory is probably the most comprehensive ever published. Chapter 6--"Glossary and General Reference Section"- -mbraces explanations of about seven hundred terms used in ornith. ological literature together with their German, Dutch and French equivalents. This glossary should render good service, especially for non-professional ornith- ologists. Appendix 1 contains the "Classification of the Habitats of British Birds", by W. B. Yapp; Appendix 2 lists 648 ornithological and zoological periodicals arranged alphabetically. Bibliography and very detailed indexes (57 pages) close this extremely useful and important book.

$$
\text { W. RYDZEWSKI }
$$

\section{Principles of Physical Metallurgy}

By Morton C. Smith. Pp. xii +417. (New York: Harper and Brothers; London : Constable and Co., Ltd., 1956.) 50s. net.

\section{Alloy Series in Physical Metallurgy}

By Morton C. Smith. Pp. $x+338$. (New York: Harper and Brothers; London: Constable and Co., Ltd., 1956.) 50s. net.

7

HESE two volumes may be taken as constituting a general account of physical metallurgy at introductory level. They would serve satisfactorily as a student's text. "The Principles of Physical Metallurgy" deals with general principles, namely, atomic considerations, crystallography, electrical and magnetic properties, and the various effects of stress on metals, including details of fracture. Some idea is also given of the types of phases present in metals. However, phase equilibria and alloying comprise the subject-matter of "Alloy Series in Physical Metallurgy", in which binary equilibrium diagrams are thoroughly discussed, followed by consideration of the structure and heat treatment of steel, and then of the cast irons, although important non-ferrous alloys are not covered to the same extent. Finally, ternary systems are briefly described and mention is made of quaternary systems.

The subject-matter included and its treatment are in the main quite conventional, although the author apparently claims some originality in these directions. One might quarrel over small points but the text is generally sound. The style of writing is sometimes laborious, the development rather drawn out, and illustrations are not always used economically.

$$
\text { A. R. BAiley }
$$

\section{German-English Mathematical Vocabulary}

By Dr. Sheila Macintyre and Edith Witte. With a Grammatical Sketch by Lilias W. Brebner. (University Mathematical Texts.) Pp. xi +95. (Edinburgh and London: Oliver and Boyd, Ltd.; New York: Interscience Publishers, Inc., 1956.) 8s. 6d. net.

Then HE young mathematician, obliged to learn enough German for professional reading, would be well advised to purchase this little book. A careful study of the thirty-page grammatical sketch, coupled with conscientious reference to the two thousand words of the skilfully selected vocabulary, should enable him to read most German mathematical works with readiness, although, of course, it will not equip him to skim a newspaper or enjoy a novel. A good plan would be to begin with one of Landau's tersely written works, and go on from there to more verbose authors. An admirable feature of the present book is a page from Ince's "Integration of Ordinary Differential Equations" faced by the corresponding page of the authorized German translation, and two similar pages from Gillespie's "Integration" and its translation. The pure mathe. matician will be grateful for this addition to the series of University Mathematical Texts ; the applied mathematician, the mathematical physicist, the statistician, may wish for a companion volume. T. A. A. Broadbent 